\title{
Synthesis and Structure of $N$-(Hydroxyethyl)ethylenediammonium Sulfite Monohydrate
}

\author{
R. E. Khoma ${ }^{a, b}$, V. O. Gelmboldt ${ }^{c}$, O. V. Shishkin ${ }^{d, e}$, V. N. Baumer ${ }^{d, e}$, \\ A. N. Puzan ${ }^{d}$, A. A. Ennan ${ }^{a}$, and I. M. Rakipov $f$ \\ ${ }^{a}$ Physicochemical Institute for Human and Environment Protection, Ministry of Education and Science of Ukraine, \\ National Academy of Sciences of Ukraine, ul. Preobrazhenskaya 3, Odessa, 65026 Ukraine \\ ${ }^{b}$ Mechnikov National University, ul. Dvoryanskaya 2, Odessa, 65025 Ukraine \\ ${ }^{c}$ Odessa National Medical University, per. Valikhovskiy 2, Odessa, 65026 Ukraine \\ ${ }^{d}$ Institute for Single Crystals, National Academy of Sciences of Ukraine, pr. Lenina 60, Kharkiv, 61178 Ukraine \\ ${ }^{e}$ Kharkiv National University, pl. Svobody 4, Kharkiv, 61077 Ukraine \\ ${ }^{f}$ Bogatskii Physicochemical Institute, National Academy of Sciences of Ukraine, \\ Lustdorfskaya doroga 86, Odessa, 65080 Ukraine \\ e-mail:rek@onu.edu.ua,r_khoma@farlep.net \\ Received December 2, 2013
}

\begin{abstract}
A reaction between sulfur(IV) oxide and aqueous $N$-(2-hydroxyethyl)ethylenediamine yields onium sulfite of composition $\left(\mathrm{HOCH}_{2} \mathrm{CH}_{2} \mathrm{NH}_{2} \mathrm{CH}_{2} \mathrm{CH}_{2} \mathrm{NH}_{3}\right) \mathrm{SO}_{3} \cdot \mathrm{H}_{2} \mathrm{O}$, which has been characterized by $\mathrm{X}$-ray diffraction, IR spectroscopy, and mass spectrometry. The three-dimensional structure of the salt is stabilized by numerous hydrogen bonds, such as $\mathrm{NH} \cdots \mathrm{O}$ and $\mathrm{OH} \cdots \mathrm{O}$.
\end{abstract}

DOI: $10.1134 / \mathrm{S} 0036023614060096$

$N$-(2-hydroxyethyl)ethylenediamine (HEEDA) and its derivatives are used as fuel additives [1], chelating agents [2], epoxy hardeners, emulsifiers, detergents, corrosion inhibitors [3], surfactants [4], and comonomers in the production of polyester materials contacting with food, enzymes, and flavorings [5]. In reactions with acids, HEEDA can be protonated at both primary and secondary amino groups; and acetate and formate salts of HEEDA manifest the properties of ionic liquids [6].

Ethanolammonium onium sulfites and hydrosulfites of unctuous consistency have been synthesized and spectrally characterized by us earlier [7,8]. The fact that the structurally studied organic sulfites are exhausted by tetramethylguanidinium hydrosulfite [9] and aminoguanidinium sulfite monohydrate [10] seems to be due to the ease for the sulfites to convert into sulfates as a result of "autooxidation" [11, 12].

In this work, we have studied the structure and spectral characteristics of $N$-(2-hydroxyethyl)ethylenediammonium sulfite monohydrate $\left(\mathrm{HOCH}_{2} \mathrm{CH}_{2} \mathrm{NH}_{2} \mathrm{CH}_{2} \mathrm{CH}_{2} \mathrm{NH}_{3}\right) \mathrm{SO}_{3} \cdot \mathrm{H}_{2} \mathrm{O}$ (I), the new onium sulfite produced in a reaction between sulfur(IV) oxide and aqueous HEEDA.

\section{EXPERIMENTAL}

Synthesis of compound I. A solution of $N$-(hydroxymethyl)ethylenediamine $(0.05 \mathrm{~mol})$ in water $(20 \mathrm{~mL})$ was poured into a temperature-con- trolled cell, and gaseous $\mathrm{SO}_{2}$ was passed through it at $0^{\circ} \mathrm{C}$ at a rate of $50 \mathrm{~mL} / \mathrm{min}$ until $\mathrm{pH}<1.0$ was attained. The solution was allowed to stand at a temperature $<15^{\circ} \mathrm{C}$ in air until water vaporized. The separated colorless crystalline product I (10.04 g; yield, $98.3 \%$ ) was not subjected to any additional purification.

Nitrogen, carbon, and hydrogen were determined on a CHN elemental analyzer; sulfur was determined by the Schôniger method [13].

For $\mathrm{C}_{4} \mathrm{H}_{16} \mathrm{~N}_{2} \mathrm{O}_{5} \mathrm{~S}$, anal. calcd. (\%): C, 23.52; N, 13.72; S, 15.70; H, 7.90.

Found (\%): C, 22.81; N, 13.34; S, 16.41; H, 8.09.

IR spectra were recorded on a PerkinElmer Spectrum BX II FT-IR System spectrometer (range: $4000-350 \mathrm{~cm}^{-1}$; $\mathrm{KBr}$ pellets).

Electron-impact (EI) mass spectra were taken on an MX-1321 mass spectrometer (direct injection; energy of ionizing electrons: $70 \mathrm{eV}$ ).

Fast atom bombardment (FAB) mass spectra were taken on a VG 7070 mass spectrometer (ions were desorbed from a liquid matrix using a beam of argon atoms with an energy of $8 \mathrm{keV}$ ).

EI mass spectrum of $m / z=87, I=6 \% ; m / z=75$, $I=11 \% ;\left[\mathrm{M}_{\mathrm{HEEDA}}-\mathrm{CH}_{2} \mathrm{OH}+\mathrm{H}\right]^{+}(\mathrm{m} / z=74, I=$ $56 \%) ; m / z=65, I=6 \% ;\left[\mathrm{SO}_{2}\right]^{+}(m / z=64, I=14 \%)$; $m / z=57, I=41 \% ; m / z=56, I=24 \% ; m / z=45, I=$ $52 \% ; m / z=46, I=9 \% ; m / z=43, I=10 \% ; m / z=34$, $I=12 \% ; m / z=32, I=100 \% ; m / z=30, I=92 \%$. The characteristics of HEEDA fragmentation products in 


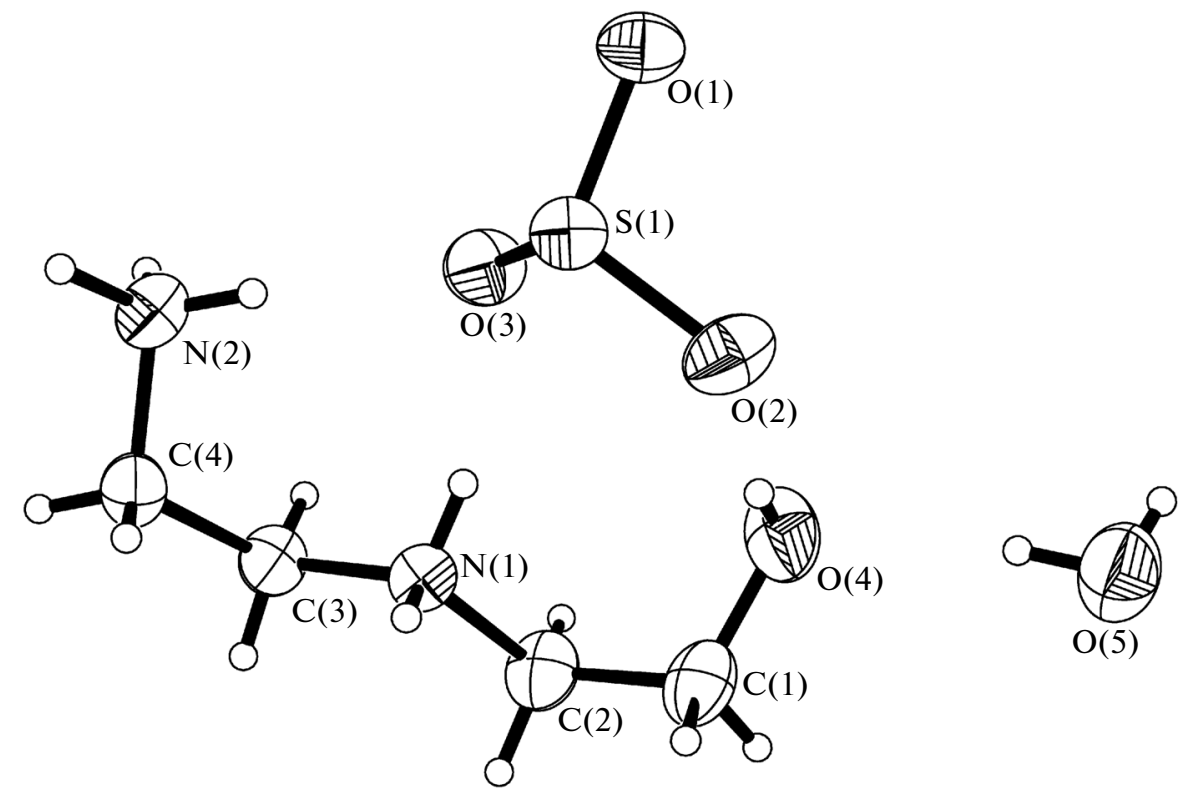

Fig. 1. Numbering of the basal atoms and the ellipsoids of thermal vibrations in the structure of compound I (50-\% probability).

the mass spectrum of compound $I$ and the tabulated HEEDA mass spectrum [14] are in good agreement.

FAB mass spectrum (solution of compound $I$ in 3-nitrobenzyl alcohol $(m / z=154, I=100 \%)$ : $[2 \mathrm{M}+$ $\mathrm{S}-2 \mathrm{H}]^{+}$dimer $(m / z=238, I=78 \%)$; fragment ions $m / z=165, I=11 \% ; m / z=130, I=8 \% ; m / z=124$, $I=18 \% ; m / z=115, I=20 \% ; m / z=107, I=35 \%$; $m / z=106, I=31 \% ; m / z=90, I=38 \% ; m / z=89, I=$ $48 \% ; m / z=88, I=16 \% ; m / z=77, I=45 \% ; m / z=76$, $I=16 \% ; m / z=69, I=12 \% ; m / z=68, I=25 \% ; m / z=$ $55, I=19 \%$.

$\mathrm{X}$-ray diffraction analysis was performed on an Oxford Diffraction Xcalibur 3 diffractometer $\left(\mathrm{Mo} K_{\alpha}\right.$ radiation, graphite monochromator, Sapphire-3 CCD detector). The structure was solved and refined using the SHELX-97 software suite [15]. Hydrogen atoms were found from a difference Fourier synthesis and refined in the isotropic approximation with overall thermal correction.

Selected crystallographic data and refinement details for the structure of compound I are the follow- ing: $\mathrm{C}_{4} \mathrm{H}_{16} \mathrm{~N}_{2} \mathrm{O}_{5} \mathrm{~S}$, monoclinic crystals, $M_{r}=204.25$, recording at $T=293(2) \mathrm{K}$, space group $P 2_{1} / n, a=$ 6.8684(11) $\AA, b=5.2264(11) \AA, c=26.358(5) \AA, \beta=$ 91.756(14) ${ }^{\circ}, V=945.7(3) \AA^{3}, Z=4, \rho=1.434 \mathrm{~g} / \mathrm{cm}^{3}$, $\mu=0.334 \mathrm{~mm}^{-1} ; F(000)=440$, crystal size $0.40 \times$ $0.20 \times 0.1 \mathrm{~mm}\left(\lambda\left(\mathrm{Mo} K_{\alpha}\right)=0.71073 \AA\right)$, transmittance coefficients $T_{\min } / T_{\max }=0.8780 / 0.9674 ;-8 \leq h \leq 5,-6 \leq$ $k \leq 6,-32 \leq l \leq 28 ; \omega$-scanning at $3.04^{\circ} \leq \theta \leq 25.99^{\circ}$; 4906 measured reflections, of which 1821 reflections are independent $\left(R_{\text {int }}=0.0505\right)$ and 1557 reflections are observed with $I_{h k l}>2 \sigma(I)$; coverage: $97.3 \%$; fullmatrix refinement on $F^{2}$, the final reliability values for the observed reflections $R_{\mathrm{F}}=0.0377, w R^{2}=0.0944$ $\left(R_{\mathrm{F}}=0.0498, w R^{2}=0.1008\right.$ for all independent reflections), $S=0.967, \Delta \rho_{\min } / \Delta \rho_{\max }=-0.300 / 0.419 \mathrm{e} / \AA^{3}$.

\section{RESULTS AND DISCUSSION}

The structure of compound I was proved by singlecrystal X-ray diffraction. The numbering of atoms and the ellipsoids of thermal vibrations in the independent

Table 1. Bond lengths and bond angles in the structure of compound I

\begin{tabular}{c|c||c||c||c|c}
\hline Bond & \multicolumn{1}{|c||}{$d, \AA$} & Bond & $d, \AA$ & Bond & $d, \AA$ \\
\hline $\mathrm{S}(1)-\mathrm{O}(1)$ & $1.5178(13)$ & $\mathrm{O}(4)-\mathrm{C}(1)$ & $1.415(3)$ & $\mathrm{N}(2)-\mathrm{C}(4)$ & $1.487(2)$ \\
$\mathrm{S}(1)-\mathrm{O}(2)$ & $1.5219(13)$ & $\mathrm{N}(1)-\mathrm{C}(2)$ & $1.481(2)$ & $\mathrm{C}(1)-\mathrm{C}(2)$ & $1.495(3)$ \\
$\mathrm{S}(1)-\mathrm{O}(3)$ & $1.5312(13)$ & $\mathrm{N}(1)-\mathrm{C}(3)$ & $1.484(2)$ & $\mathrm{C}(3)-\mathrm{C}(4)$ & $1.500(3)$ \\
\hline Angle & \multicolumn{2}{|c||}{$\omega, \mathrm{deg}$} & \multicolumn{2}{c}{ Angle } & $\omega, \operatorname{deg}$ \\
\hline $\mathrm{O}(1) \mathrm{S}(1) \mathrm{O}(2)$ & & $105.65(7)$ & $\mathrm{O}(4) \mathrm{C}(1) \mathrm{C}(2)$ & $112.95(17)$ \\
$\mathrm{O}(1) \mathrm{S}(1) \mathrm{O}(3)$ & & $103.40(6)$ & $\mathrm{N}(1) \mathrm{C}(2) \mathrm{C}(1)$ & $111.82(16)$ \\
$\mathrm{O}(2) \mathrm{S}(1) \mathrm{O}(3)$ & & $103.87(7)$ & $\mathrm{N}(2) \mathrm{C}(3) \mathrm{C}(4)$ & $112.81(15)$ \\
$\mathrm{C}(2) \mathrm{N}(1) \mathrm{C}(3)$ & & $113.73(14)$ & & $112.89(15)$ \\
\hline
\end{tabular}


Table 2. Parameters of $\mathrm{D}-\mathrm{H} \cdots \mathrm{A}$ hydrogen bonds in the structure of compound I

\begin{tabular}{l|l|l|l|l|l}
\hline \multirow{2}{*}{$\mathrm{D}-\mathrm{H} \cdots \mathrm{A}$ contact } & \multicolumn{3}{|c|}{ Distance, $\AA$} & \multicolumn{1}{|c}{$\begin{array}{c}\text { DHA } \\
\text { angle, deg }\end{array}$} & \multicolumn{1}{|c}{ Atom A coordinates } \\
\cline { 2 - 4 } & $\mathrm{D}-\mathrm{H}$ & $\mathrm{H} \ldots \mathrm{A}$ & \multicolumn{1}{|c}{$\mathrm{D} \ldots \mathrm{A}$} & \\
\hline $\mathrm{O}(5)-\mathrm{H}(5 \mathrm{~B}) \cdots \mathrm{O}(5)$ & $0.78(2)$ & $2.17(2)$ & $2.938(2)$ & $173(3)$ & $-x+3 / 2, y-1 / 2,-z+1 / 2$ \\
$\mathrm{O}(4)-\mathrm{H}(4 \mathrm{C}) \cdots \mathrm{O}(2)$ & $0.74(2)$ & $1.92(2)$ & $2.644(2)$ & $170(2)$ & $x, y, z$ \\
$\mathrm{O}(5)-\mathrm{H}(5 \mathrm{~A}) \cdots \mathrm{O}(4)$ & $0.84(2)$ & $1.95(2)$ & $2.782(2)$ & $171(2)$ & $x, y, z$ \\
$\mathrm{~N}(1)-\mathrm{H}(1 \mathrm{C}) \cdots \mathrm{O}(3)$ & $0.86(2)$ & $1.88(2)$ & $2.711(2)$ & $160(2)$ & $x, y, z$ \\
$\mathrm{~N}(1)-\mathrm{H}(1 \mathrm{D}) \cdots \mathrm{O}(1)$ & $0.77(2)$ & $2.07(2)$ & $2.8236(19)$ & $168(2)$ & $x, y+1, z$ \\
$\mathrm{~N}(1)-\mathrm{H}(1 \mathrm{D}) \cdots \mathrm{O}(3)$ & $0.77(2)$ & $2.50(2)$ & $3.038(2)$ & $128.9(19)$ & $x, y+1, z$ \\
$\mathrm{~N}(2)-\mathrm{H}(2 \mathrm{C}) \cdots \mathrm{O}(3)$ & $0.88(2)$ & $1.91(2)$ & $2.784(2)$ & $172(2)$ & $x, y, z$ \\
$\mathrm{~N}(2)-\mathrm{H}(2 \mathrm{D}) \cdots \mathrm{O}(1)$ & $0.99(2)$ & $1.84(2)$ & $2.784(2)$ & $160.1(17)$ & $-x,-y,-z$ \\
$\mathrm{~N}(2)-\mathrm{H}(2 \mathrm{E}) \cdots \mathrm{O}(2)$ & $0.85(2)$ & $1.89(2)$ & $2.742(2)$ & $175(2)$ & $x-1, y, z$ \\
\hline
\end{tabular}

cell part are shown in Fig. 1. Bond lengths and bond angles formed by non-hydrogen atoms in the structure are listed in Table 1. The independent cell part is built of a $\mathrm{C}_{4} \mathrm{H}_{14} \mathrm{~N}_{2} \mathrm{O}^{2+}$ cation, an $\mathrm{SO}_{3}^{2-}$ sulfite ion, and a water molecule. The packing of these basal units forms a network of hydrogen bonds in the crystal structure (Table 2). The hydrogen atoms that are bonded to oxygen or nitrogen atoms participate in the formation of hydrogen bonds in the structure. The terminal ammonium group ( $\mathrm{N}(2)$ atom) forms hydrogen bonds with three nearest-neighboring sulfite ions; the $\mathrm{NH}_{2}$ group (N(1) atom) forms hydrogen bonds with two sulfite ions, and its bond with one of these ions is forklike (Table 3). Water molecules form hydrogen bonds with the hydroxy group of the cation and also with each other. The network of hydrogen bonds observed in the structure of compound $\mathbf{I}$ is three-dimensional (Fig. 2).

The results of analyzing the IR spectrum of compound $\mathbf{I}$ are given in Table 3; the assignment of vibrations was performed using published data [16-18].

The intense absorption bands with smeared maxima at 3401 and $3014 \mathrm{~cm}^{-1}$ in the IR spectrum of compound I were assigned to the $v(\mathrm{OH})$ and $v(\mathrm{NH})$ stretching vibrations of the onium cation and the water molecules that participate in the network of hydrogen bonds. The $\mathrm{SO}_{3}^{2-} v_{\mathrm{as}, \mathrm{s}}\left(\mathrm{SO}_{3}^{2-}\right)$ stretching vibrations of the pyramidal $\mathrm{SO}_{3}^{2-}$ anion appeared as a series of mediumintensity bands at 1004, 983,966, and $920 \mathrm{~cm}^{-1}$, which were absent in the spectrum of HEEDA. The band of $\delta_{\mathrm{s}}\left(\mathrm{SO}_{3}^{2-}\right)$ bending vibrations seemed to be incorporated into the complex intense band at $619 \mathrm{~cm}^{-1}$. The $\delta_{\mathrm{d}}\left(\mathrm{SO}_{3}^{2-}\right)$ doubly degenerated out-of-plane bending vibrations were identified in the form of low-intensity bands at 516 and $487 \mathrm{~cm}^{-1}$.
Hence, the reaction product in $\mathrm{SO}_{2}-$ $\mathrm{HOCH}_{2} \mathrm{CH}_{2} \mathrm{NHCH}_{2} \mathrm{CH}_{2} \mathrm{NH}_{2}-\mathrm{H}_{2} \mathrm{O}$ solutions is $\mathrm{N}$-(2-hydroxyethyl)ethylenediammonium sulfite monohydrate $\left(\mathrm{HOCH}_{2} \mathrm{CH}_{2} \mathrm{NH}_{2} \mathrm{CH}_{2} \mathrm{CH}_{2} \mathrm{NH}_{3}\right) \mathrm{SO}_{3} \cdot \mathrm{H}_{2} \mathrm{O}$, whose three-dimensional structure is stabilized by a network of hydrogen bonds with the participation of all the "active" hydrogen atoms of the onium cation. The effects of hydrogen bonds obviously result in the

Table 3. Wavenumbers $\left(\mathrm{cm}^{-1}\right)$ of absorption band maxima in the IR spectra of HEEDA and compound $\mathbf{I}$

\begin{tabular}{|c|c|c|}
\hline $\begin{array}{c}\text { HEEDA } \\
{[16]}\end{array}$ & Assignment & I \\
\hline $\begin{array}{l}3170 \mathrm{~m} \\
2828 \mathrm{~s}\end{array}$ & $v(\mathrm{NH}), v(\mathrm{OH})$ & $\begin{array}{l}3401 \text { vs. b. } \\
3014 \text { vs. b. }\end{array}$ \\
\hline $1602 \mathrm{~m}$ & $\delta\left(\mathrm{NH}_{2}\right), \delta(\mathrm{HOH}), \delta(\mathrm{CNH})$ & $1624 \mathrm{~s}$ \\
\hline \multirow[t]{2}{*}{$\begin{array}{l}1453 \mathrm{~m} \\
1359 \mathrm{~m}\end{array}$} & $\delta(\mathrm{CNH}), v(\mathrm{CN})$ & $\begin{array}{l}1496 \mathrm{~m} \\
1454 \mathrm{~m} \\
1329 \mathrm{w}\end{array}$ \\
\hline & $\omega(\mathrm{NH})$ & $1234 \mathrm{w}$ \\
\hline \multirow[t]{2}{*}{$\begin{array}{l}1178 \mathrm{~m} \\
1127 \mathrm{~s} \\
1054 \mathrm{vs}\end{array}$} & $\begin{array}{l}v(\mathrm{CO}), v(\mathrm{CN}), \rho\left(\mathrm{NH}_{2}\right), \\
\delta(\mathrm{CNH})\end{array}$ & 1125 vs \\
\hline & $v_{\text {as, } s}\left(\mathrm{SO}_{3}^{2}\right)$ & $\begin{array}{r}1004 \mathrm{~m} \\
983 \mathrm{~m} \\
966 \mathrm{~m} \\
920 \mathrm{~m}\end{array}$ \\
\hline \multirow[t]{4}{*}{$771 \mathrm{~s}$} & $\omega\left(\mathrm{NH}_{2}\right)$ & $783 \mathrm{w}$ \\
\hline & $\delta_{\mathrm{s}}\left(\mathrm{SO}_{3}^{2-}\right), \rho\left(\mathrm{NH}_{2}\right), \gamma\left(\mathrm{H}_{2} \mathrm{O}\right)$ & $\begin{array}{l}663 \mathrm{sh} \\
619 \mathrm{vs}\end{array}$ \\
\hline & $\tau\left(\mathrm{NH}_{2}\right), \delta(\mathrm{CNH}), \delta\left(\mathrm{CN}_{3}\right)$ & $579 \mathrm{w}$ \\
\hline & $\delta_{\mathrm{d}}\left(\mathrm{SO}_{3}^{2-}\right)$ & $\begin{array}{l}516 \mathrm{w} \\
487 \mathrm{w}\end{array}$ \\
\hline
\end{tabular}

$\delta$ stands for scissoring, $\delta_{\mathrm{d}}$ for out-of-plane, $\omega$ for wagging, $\tau$ for twisting, $\rho$ for rocking, and $\gamma$ for librational vibrations. 


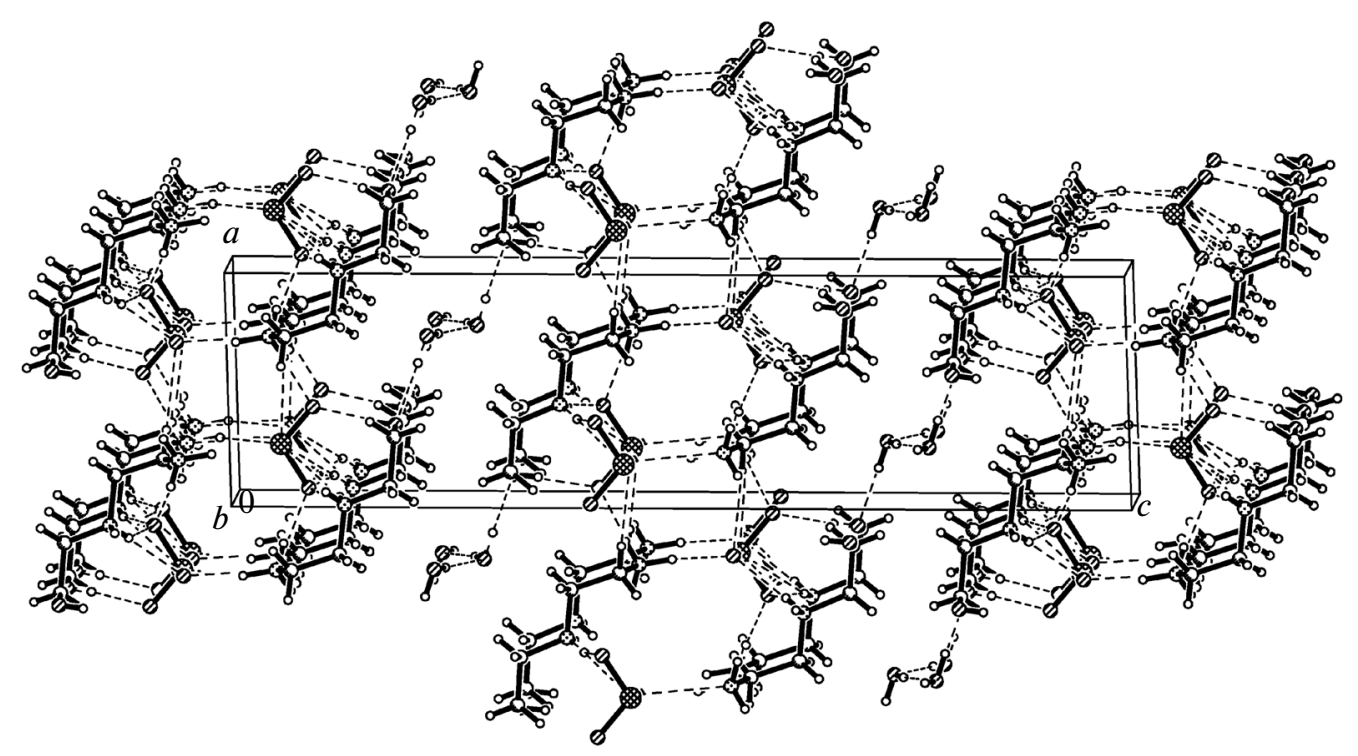

Fig. 2. Network of hydrogen bonds in the structure of compound I (hydrogen atoms are omitted).

observed distortions of the pyramidal geometry of the sulfite anion in the structure of the complex.

\section{REFERENCES}

1. J. L. Dever, M. C. Menon, S. D. Phillips, and L. J. Baldwin, US Patent 5508356 (1996).

2. A. Karadag, H. Pasaoglu, G. Kastas, and O. Büyükgüngör, Zeit. Kristallogr.-Cryst. Mater. 220 (1), 74 (2005).

3. The Chemical Encyclopedia, Ed. by N. S. Zefirov (Bol'shaya Rossiiskaya Entsiklopediya, Moscow, 1995), p. 147 [in Russian].

4. J. A. Krogh, G. N. Taylor, D. S. Treybig, and M. J. Williams, US Patent 6964940 (2005).

5. EFSA J. 10, 2653 (2012). doi:10.2903/j.efsa.2012.2653

6. A. Destegul, J. Mol. Liq. 177, 369 (2013).

7. R. E. Khoma, V. O. Gel'mbol'dt, L. V. Koroeva, et al., Vopr. Khim. Khim. Tekhnol., No. 1, 133 (2012).

8. R. E. Khoma, A. A. Ennan, A. V. Mazepa, et al., Vopr. Khim. Khim. Tekhnol., No. 1, 136 (2013).

9. D. J. Heldebrant, C. R. Yonker, P. G. Jessop, and L. Phan, Chem.-Eur. J. 15, 7619 (2009).
10. R. E. Khoma, V. O. Gel'mbol'dt, V. N. Baumer, et al., Russ. J. Inorg. Chem. 58, 843 (2013).

11. R. E. Khoma, A. A. Ennan, O. V. Shishkin, et al., Russ. J. Inorg. Chem. 57, 1559 (2012).

12. R. E. Khoma, V. O. Gel'mbol'dt, O. V. Shishkin, et al., Russ. J. Inorg. Chem. 59, 1 (2014).

13. V. A. Klimova, Major Techniques of Organic Analysis (Khimiya, Moscow, 1975) [in Russian].

14. G. M. Sheldrick, Acta Crystallogr., Sect. A 64, 112 (2008).

15. http://webbook.nist.gov/cgi/cbook.cgi? ID $=$ C111411\& Mask $=200 \#$ Mass-Spec

16. http://ihcp.jrc.ec.europa.eu/our_databases/eurl-fcmref-coll/reference-substances/ft/A130.pdf

17. K. Nakamoto, Infrared and Raman Spectra of Inorganic and Coordination Compounds (Interscience, New York, 1986).

18. E. Pretsch, P. Buhlmann, and C. Affolter, Structure Determination of Organic Compounds. Tables of Spectral Data (Springer, 2000; Mir, BINOM. Laboratoriya znanii, Moscow, 2006).

Translated by E. Glushachenkova 